\title{
MAKANAN TRADISIONAL DI KABUPATEN CIAMIS
}

\section{Traditional Food in Regency of Ciamis}

\author{
Oleh Aam Masduki \\ Balai Pelestarian Sejarah dan Nilai Tradisional Bandung \\ Jln. Cinambo No. 136 Ujungberung - Bandung \\ Email:aam@yahoo.com
}

Naskah Diterima: 27 April 2012

Naskah Disetujui: 30 Mei 2012

\begin{abstract}
Abstrak
Makanan merupakan kebutuhan yang esensial bagi manusia. Keberadaan makanan tersebut dibutuhkan sebagai sumber energi dan zat tertentu untuk mengatur proses metabolisme. Eksistensi makanan dalam kehidupan masyarakat tidak terbatas hanya untuk memenuhi kepentingan tersebut. Ada nilai sosial atau makna lainnya yang tersirat di balik rasa, warna, dan bentuk suatu makanan. Wujud akhir dari proses tersebut adalah terciptanya jenis dan bentuk makanan berikut peruntukannya, seperti makanan untuk upacara adat atau kenduri, makanan untuk persembahan kepada entitas supranatural, dan makanan dibuat pada saat-saat tertentu. Tujuan dari penelitian ini yaitu untuk mendokumentasikan jenis-jenis makanan yang ada di kabupaten Ciamis. Metode penelitian yang digunakan bersifat deskripsi dengan pendekatan kualitatif melalui pengumpulan data berupa wawancara dan pengamatan. Respon kebudayaan terhadap kebutuhan dasar berupa makan akan beragam, mengingat beranekanya kebudayaan yang dimiliki manusia. Tidaklah heran jika budaya masyarakat Indonesia di seputar makan pun akan berbeda antara suku bangsa yang satu dan lainnya. Perbedaan pun terjadi pada suku bangsa yang sama, namun menempati lingkungan alam, lingkungan sosial, dan lingkungan transenden yang berlainan. Dengan demikian perihal makan ini ada di bawah kendali kebudayaan. Beberapa respon kebudayaan di seputar kebutuhan dasar berupa makan di antaranya perilaku makan, cara mendapatkan, mengolah dan membuat makanan, dan makanan sendiri sebagai hasil dari proses.
\end{abstract}

Kata kunci : makanan, khas, Ciamis.

\begin{abstract}
Food is an essential need to human being. It serves energy resources for our body as well as social values reflecting in many kinds of food for different kind of events and situations. This is a cultural respond to the need for food. Every ethnic groups in Indonesia has their own eating habit. It is interesting to know that natural and social environments can affect the habit, even in the same ethnic group. Therefore, culture controls food. It is reflected in eating behaviour, how to get and process food, and the food itself.
\end{abstract}

Keywords: food, specialty, Ciamis. 


\section{A. PENDAHULUAN}

Makanan tradisional banyak ditemukan di semua daerah di Indonesia. Makanan khas Ciamis cukup menarik untuk diangkat menjadi judul tulisan, karena sebagian besar masyarakat Indonesia belum mengenal jenis-jenis makanan yang ada di Ciamis.

Ada dua tujuan yang ingin dicapai melalui tulisan tentang makanan tradisional di Kabupaten Ciamis, yakni tujuan khusus dan tujuan umum. Tujuan khusus dari tulisan ini adalah sebagai berikut:

1. Mengidentifikasi tentang jenis-jenis makanan tradisional di Kabupaten Ciamis yang merupakan bagian tak terpisahkan dari kehidupan masyarakatnya.

2. Untuk mengetahui berbagai jenis makanan yang biasa dikonsumsi oleh masyarakat di Kabupaten Ciamis.

Tujuan umum yang ingin dicapai dari tulisan ini adalah untuk melengkapi data budaya di Balai Pelestarian Sejarah dan Nilai Tradisional (BPSNT) Bandung. Data dan informasi tersebut pada gilirannya dapat dijadikan bahan kebijakan dalam pelestarian kesejarahan dan kebudayaan itu sendiri. Ruang lingkup tulisan terbagi menjadi dua, yakni materi dan wilayah. Ruang lingkup wilayah dibatasi di wilayah Kabupaten Ciamis Provinsi Jawa Barat, satu dari empat wilayah kerja Balai Pelestarian Sejarah dan Nilai Tradisional (BPSNT) Bandung yang meliputi Provinsi Jawa Barat, Banten, DKI Jakarta, dan Lampung.

Ruang lingkup materi adalah berbagai jenis makanan tradisional yang ada di Ciamis meliputi: nama makanan, bahan dasar makanan, dan cara pengolahan. Ciamis dipilih sebagai wilayah tentang makanan tradisional, semata-mata karena data mengenai hal ini relatif sulit didapat, bahkan mungkin belum dilaksanakan inventarisasi yang berujung pada laporan/data tertulis tentang makan tradisional. Metode yang digunakan untuk penyusunan data tentang makanan khas Ciamis adalah metode deskriptif dalam bentuk kualitatif, dengan teknik pengumpulan data berupa observasi partisipasi/pengamatan, wawancara mendalam dengan beberapa informan dan pengunjung makanan, serta studi pustaka.

\section{B. HASIL DAN BAHASAN}

\section{Apem}

Makanan ini terbuat dari bahan dasar tepung beras, tape singkong atau tape nasi. Bahan dan alat yang digunakan: air panas, gula pasir, gincu atau ontan. Alat yang diperlukan adalah cetakan, langseng.

Cara pengolahan: Semua bahan mentah dicampur dengan air panas, diaduk hingga merata dengan bumbu, lalu ditutup sampai mekar. Kemudian cetakan kue diisi dengan adonan tadi, lalu dikukus hingga masak.

\section{Angleng}

Asal bahan mentah dari makanan ini adalah tepung beras, gula merah, kelapa. Bahan dan alat yang digunakan: gula merah, air, kulit jagung. Alatnya kuali.

Cara pengolahannya: tepung beras, gula merah dan kelapa parut, diaduk sambil dipanaskan di atas api. Setelah kering dibungkus dengan cangkang "kulit" buah jagung.

\section{Galendo}

Makanan ini terbuat dari bahan dasar kelapa. Adapun cara pengolahannya adalah sebagai berikut:

1. Daging kelapa dibersihkan, lalu diparut dengan parut atau mesin.

2. Kelapa yang sudah diparut diambil airnya (santan). 
3. Kelapa dikupas dan dicungkil dagingnya lalu dibersihkan.

4. Air santan dimasak hingga mendidih sampai air habis, lalu menggumpal, dan jadilah galendo yang berbaur dengan minyak.

5. Serbuk galendo diangkat dan disimpan pada cetakan lalu dibungkus dengan anyaman bambu.

6. Serbuk galendo dipadatkan dengan cara dipres, selain untuk dipadatkan juga untuk memisahkan galendo dengan minyaknya.

7. Setelah itu galendo yang sudah padat dipotong-potong dan di kemas. Begitu juga dengan minyak dari galendo tersebut dikemas pula.

Bapak Endut adalah salah seorang pengrajin galendo yang masih terus bertahan memproduksi makanan khas Ciamis. Ia tak hanya mempertahankan keaslian galendo tetapi juga memproduksi galendo kontemporer dengan segala inovasinya. Di antaranya berupa galendo rasa asli, yaitu galendo yang dibungkus dengan anyaman bambu kemudian dikemas lagi dengan kotak plastik mirip kemasan brownis. Kemudian galendo rasa keju, rasa pisang, dan rasa wijen. Galendo ala oreo, galendo ala silverqueen hingga galendo bubuk.

Di antara berbagai jenis galendo tersebut, galendo rasa asli yang dibungkus anyaman bambu tetap merupakan jenis galendo yang paling digemari (favorit). Sedangkan untuk anak muda, pihaknya menyediakan galendo dengan berbagai variasi dan inovasi hingga tampilan lebih gaul. Harga galendo pun bervariasi mulai dari $\mathrm{Rp} 3.000,-$ sampai $\mathrm{Rp} 3.500$,tergantung jenis dan bentuk. Selain itu bapak Endut juga membuat galendo dengan kemasan baru berupa kemasan dus, tas jinjing, dan yang terbaru adalah kemasan mika mirip brownis, serta pembungkus mengkilat untuk galendo ala silverqueen. Hal baru yang penting diperhatikan, jika dulu galendo produksi bapak Endut hanya bertahan 15 hari sampai satu bulan, sekarang dengan teknologi vakum, galendo bapak Endut bisa bertahan 3-5 bulan. Dengan teknologi vakum, kadar air dan kadar tengiknya bisa diatasi.

\section{Abon}

Abon daging adalah makanan kering yang terbuat dari suiran-suiran daging dan bumbu-bumbu. Daging direbus atau dikukus, kemudian disuir, dicampur dengan bumbu dan digoreng sampai matang menjadi bumbu. Bumbu dan bahan yang digunakan:

- Daging (10 kg)

- Bawang merah (1 kg). Sebanyak 750 gram dari bawang ini dijadikan bawang goreng.

- Bawang putih (400 gram)

- Bubuk ketumbar (50 gram)

- Lengkuas (50 gram)

- Daun salam (15 lembar)

- Sereh (7 potong)

- Gula pasir (750 gram)

- Asam jawa (50 gram)

- Santan kental (2000 ml)

Cara pengolahan:

1. Menyiapkan suiran daging. Daging dipotong-potong kemudian direbus selama 1 jam. Setiap $1 \mathrm{~kg}$ daging direbus dengan $1 / 2$ liter air. Setelah itu, daging disuir-suir dan ditumbuk pelan-pelan sehingga menghasilkan serat-serat halus.

2. Menyiapkan bumbu dan santan. Lengkuas dan sereh dipukulpukul sampai memar. Bawang merah (350 gram), bawang putih dan ketumbar digiling halus, kemudian ditumis. Setelah agak harum, ditambahkan santan kental, lengkuas, asam jawa, 
gula, daun salam dan sereh. Pemanasan diteruskan sampai mendidih dan volume santan tinggal setengahnya.

3. Memasak abon: a) Suiran daging dimasukkan sedikit demi sedikit ke dalam santan mendidih. Api dikecilkan sekadar menjaga santan tetap mendidih. Pemanasan disertai pengadukan dilakukan sampai bahan setengah kering. Hasil yang diperoleh disebut dengan abon lembab. b) Abon lembab diangkat, kemudian digoreng di dalam minyak panas (suhu 1700C) sampai garing (bila diremas berkemerisik).

4. Abon panas yang baru diangkat dari minyak harus segera ditiriskan. Dianjurkan dengan menggunakan alat peniris sentrifugal, alat pres ulir, atau alat pres hidrolik. Setelah ditiriskan dengan alat peniris sentrifugal, atau alat pres, abon dipisah-pisah.

5. Pencampuran dengan bawang goreng. Abon yang telah ditiriskan dicampur dengan bawang goreng. Hasil yang diperoleh disebut abon daging.

6. Pengemasan. Abon daging dikemas di dalam kemasan yang tertutup rapat. Kantong plastik merupakan salah satu kemasan yang cukup baik digunakan untuk mengemas abon.

\section{Cuhcur}

Makanan ini terbuat dari bahan dasar tepung beras ditambah terigu. Bumbu dan bahan yang digunakan:

- $475 \mathrm{ml}$ air

- 150 gram gula merah

- 100 gram gula pasir
- 2 lembar daun pandan

- 300 gram tepung beras

- 50 gram tepung terigu

- 1 butir telur

- 1/4 sendok teh garam

- minyak untuk menggoreng

Cara pengolahan:

1. Air, gula merah, gula pasir dan daun pandan direbus lalu disaring.

2. Rebusan dituangkan ke campuran tepung beras dan terigu sambil diaduk perlahanlahan.

3. Adonan didiamkan semalam, esok harinya dimasukkan telur dan garam secukupnya lalu diaduk sampai rata. Panaskan 2 sendok sayur minyak di wajan kecil, lalu tuangkan 1 sendok sayur adonan dan goreng sampai satengah matang.

\section{Mustopa}

Sambal goreng kentang mustopa merupakan produk makanan olahan dari resep keluarga yang sudah ada sejak tahun 60-an dan sampai sekarang masih tetap dipertahankan. Produk makanan olahan ini, sekitar tahun 80-90-an menjadi ciri tersendiri bagi masyarakat Kabupaten Ciamis, karena produk ini sudah cukup terkenal di masyarakat. Tidak hanya itu, makanan olahan ini selalu dicari oleh orang-orang untuk menjadi oleh-oleh atau cenderamata bagi mereka yang berkunjung ke Kota Manis Ciamis.

Sambal goreng kentang mustopa, sangat cocok bila dimakan bersama nasi hangat dan sebagai penyerta pada saat makan pagi, makan siang ataupun makan malam. Sekarang para konsumen, tidak hanya menjadikan sambal goreng kentang mustopa ini untuk dikonsumsi sendiri, tapi juga bisa menjadi buah tangan untuk para sahabat, kolega, kerabat, saudara atau 
sebagai hantaran di saat lebaran tiba. Sambal goreng kentang mustopa produksi Hj. Nanny Ellan memiliki keistimewaan karena tektur dari kentang yang garing, renyah, serta perpaduan rasa bumbu yang khas menjadikan sambal goreng kentang ini dapat di konsumsi langsung. Selain itu keaslian dan kualitas dari kentang pilihan yang sangat dijaga dan diperhatikan, sehingga membuat sambal goreng ini lebih terasa nikmat dan lezat. Keistimewaan lainnya, sambal goreng kentang ini dapat bertahan lebih dari 6 bulan. Semakin lama disimpan, kualitas rasa malah semakin enak dan nikmat. Adapun bumbu dan bahan yang digunakan:

- Kentang ukuran sedang (biasa menggunakan kentang Dieng),

- cabe merah,

- bawang putih,

- bawang merah,

- gula secukupnya,

- garam secukupnya,

- penyedap rasa,

- udang kering yang sudah ditumbuk.

Cara pengolahan:

- Proses awal:

Kentang dicuci bersih, dikupas kulitnya, lalu direndam dalam air kapur. Kentang selanjutnya diserut dengan menggunakan parutan kecil, hingga seluruh kentang terparut habis. Rendam parutan kentang dalam air dingin, lalu beri sedikit campuran air dan kapur. Cuci bersih dan bilas kentang yang telah direndam, lalu tiriskan di atas saringan agar air dalam kentang benar-benar berkurang, diamkan beberapa saat.

- Pengolahan bumbu:

- Cuci bersih cabe merah, buang bijinya, iris kecil-kecil.

- Kupas bawang putih, potongpotong.

- Kupas bawang merah, potongpotong.
- Tumbuk sampai halus ebi kering, ayak hingga mendapatkan bagian yang paling lembut.

- Masukkan irisan cabe merah ke dalam food prosesor, beri sedikit air, proses hingga menjadi cair.

- Masukkan potongan bawang putih, bawang merah, blender jadi satu hingga halus, angkat sisihkan.

- Bumbu siap untuk digunakan.

Proses pengolahan:

Panaskan wajan ukuran besar, masukkan minyak goreng hingga setengah wajan, panaskan. Setelah minyak goreng panas, masukkan parutan kentang yang telah kering, masukkan sebagian-sebagian sesuai ukuran wajan.Tunggu beberapa saat, hingga campuran kentang dan minyak mulai berkurang letupannya. Aduk sekalisekali, terutama bila ada kentang yang bergumpal

Setelah setengah matang, angkat kentang dari wajan, tiriskan dalam saringan hingga minyak berkurang Panaskan wajan satunya, masukkan minyak goreng, goreng kembali kentang yang telah ditiriskan. Aduk-aduk hingga kentang betul-betul sudah kering menyerap, angkat, tiriskan. Panaskan wajan ukuran besar, masukkan bumbu yang sudah dihaluskan, cabe merah, campuran bawang putih dan bawang merah dan udang kering. Tunggu hingga bumbu matang dan harum. Masukkan kentang yang telah ditiriskan dari penggorengan kedua, aduk rata dengan seluruh bumbu. Kecilkan api, aduk hingga seluruh bahan tercampur dengan merata. Goreng terus kentang di atas api kecil, hingga kentang betul-betul kering dan garing. Setelah matang, angkat kentang, tiriskan di atas tempat datar, tunggu hingga kentang goreng dingin dengan sendirinya. Simpan sambal goreng kentang dalam wadah/toples/kaleng tertutup rapat.

Sambal goreng kentang ini dapat bertahan dalam waktu lebih dari 6 bulan, bila disimpan dalam jangka waktu lama 
dan akan dipergunakan kembali, maka tinggal menggoreng kentang menggunakan api kecil, maka sambal goreng kentang siap untuk digunakan.Tetapi bila tidak terlalu lama disimpan, maka sambal goreng kentang ini bisa langsung dikonsumsi.

\section{Sale Pisang}

Suka Senang merupakan salah satu industri yang cukup besar di daerah Ciamis, yang berlokasi di Jalan Raya Ciamis Km 6. Produk utamanya berbahan dasar pisang, yang diolah menjadi keripik dan sale dengan berbagai rasa dan jenis. Ada sale gulung, sale lidah, sale opak, sale pisang ambon, keripik pisang asin, manis, dan pedas manis. Khusus sale, menggunakan jenis pisang siam dan ambon, sedangkan untuk keripik pisang menggunakan pisang kapas atau pisang nangka.

Resep produk ini diracik oleh $\mathrm{Hj}$. Odah Zubaedah, istri dari Bapak Tarwa Hadi, pemilik sale pisang. Resepnya ini tanpa bahan pengawet. Orientasinya adalah produk yang tahan lama (kurang lebih 6 bulan), dengan rasa gurih, kering, dan renyah.

Indrustri ini mendapat bintang 1 dari BP POM Ciamis dalam bidang produk unggulan yang higienis dan juga beberapa penghargaan lainnya. Selain itu, pabrik ini juga sering menjadi target kunjungan orang yang hendak membuka usaha. Ada yang dari Yogyakarta, Cianjur, Bandung, Majalengka hingga Sulawesi. Hingga kini, produk ini sudah menembus ke berbagai daerah, seperti Batam, Bali, Jakarta, Sumatra bahkan sudah mulai merambah hingga ke berbagai negara seperti Hongkong, Singapura dan Kanada. Sale atau pisang olahan kering sudah menjadi cemilan khas daerah Jawa Barat.

Bisnis sale pun menjadi menggiurkan jika ditangani dengan serius. Bapak Tarwa Hadi seorang pegawai
Perhutani mempercepat masa pensiunnya dengan mencoba keberuntungan di bisnis olahan pisang sale dan kripik. Pria asal Ciamis ini memulai bisnisnya sejak tahun 1996 silam atas desakan sang istri. Ia sadar berbisnis makanan tidaklah mudah karena terkait dengan keharusan bisa memanjakan lidah konsumen. Awalnya hanya cobacoba, mengevaluasi setiap kekurangan, dan menerima masukan atau kritikan dari orang lain. Hasilnya sampai sekarang, ia tidak hanya berhasil menjalankan bisnisnya, namun ia juga mampu memberdayakan masyarakat di sekitar rumahnya.

Setidaknya saat ini ia mampu merekrut 60 pegawai langsung. Selain itu ia juga telah membina kurang lebih 120 kepala keluarga sebagai pemasok potongan pisang, kuli pemanggul, dan petani pisang, Untuk sale pisang dibuat dari pisang siam, pisang nangka, pisang kapas, pisang ambon. Sampai saat ini produk sale dan kripiknya laku dijual di beberapa kota besar di Indonesia seperti Bandung, Jakarta, Medan, Surabaya. Bahkan sejak lima tahun lalu, sudah diekspor ke Kanada dan negara lainnya seperti Malaysia, Brunei, dan Taiwan.

\section{Keripik Singkong}

Bermula dari sekedar iseng ketika pada tahun 1997 Bapak Uju Sarju (60) memulai usahanya membuat keripik singkong. Setelah ada pembelinya, Bapak Uju tidak hanya membuat keripik singkong, tetapi mengembangkan ke keripik talas dan pisang. Usaha itu dilakukan di rumahnya di Cisaga, Kabupaten Ciamis, Provinsi Jawa Barat.

Produksi keripik singkong Bapak Uju, selain dijual ke pasar dan ke warungwarung, dibeli sebagai oleh-oleh ke luar negeri. Bapak Uju mempekerjakan delapan orang karyawan dengan sebuah mesin potong keripik dan tiga penggorengan dengan ukuran besar. Keripik singkong, 
talas, dan pisang buatan Bapak Uju tahan lama, tanpa bahan pengawet, dan dibuat dengan bumbu rempah-rempah lokal. Keripik singkong keripik talas dikemas dalam kantong plastik yang higienies. Keripik kemasan plastik tebal inilah inovasi yang diterapkan Bpak Uju untuk memenuhi pasar. Selain tahan lama, kemasan plastik lebih cocok bagi konsumen yang kian terbiasa dengan gaya hidup praktis.

Bahan baku singkong, talas dan pisang tersedia di daerahnya. Dengan bahan baku pilihan, sehari menghabiskan singkong, talas, dan pisang sebanyak dua kwintal, dengan minyak kelapa keletik. Bahan bakar penggorengan tidak menggunakan kayu bakar, melainkan memakai serbuk gergaji dari potongan kayu. Pengapian itu sangat bagus untuk menghasilkan kematangan keripik yang pas dan renyah. Harga serbuk gergaji dari potongan kayu per karung Rp 2.500 . Modal produksi per hari $\mathrm{Rp} 700$ ribu dengan meraup keuntungan $40 \%$. Modal awal Uju mengeluarkan 5 juta, termasuk mencakup peralatan dan bahan-bahan kebutuhan produksi. Harga jual keripik singkong dan talas 15 ribu/kg, keripik pisang $20 \mathrm{ribu} / \mathrm{kg}$, tersedia juga keripik balado pedas manis dan asin harga 20 ribu. Pelanggan tidak hanya lokal Banjar dan Ciamis, tapi juga ke luar daerah sebagai oleh-oleh. Bahkan sampai ke kota-kota besar seperti Bandung, Jakarta, Yogyakarta, Bali, Sumatera, Kalimantan bahkan ke Papua juga ke luar negeri, dan menembus hingga ke Amerika dan Jerman.

\section{Colok Gemyung (Sate Jepret)}

Makanan tradisi yang sangat melegenda di Ciamis tidak hanya galendo, tapi juga colok gembrung. Colok gembrung ini disebut juga dengan sate jepret. Maklum, sejatinya colok gembrung ini merupakan sate kulit sapi (kikil). Colok gembrung ini memang makanan cemilan yang terbuat dari kulit sapi yang dipotong- potong setelah direbus, kemudian ditusuk dengan lidi kelapa persis seperti sate. Lantas dilumuri bumbu dari berbagai bahan sehingga terasa sekali rasa gurihnya. Disebut sate jepret, mungkin karena penyajiannya seperti sate. Ditusuk lidi dan makannya pun seperti makan sate. " Kenapa diberi nama colok gembrung, tidak tahu persis. Tapi sebutan ngetopnya memang colok gembrung," ujar Teti Roheyati (42), salah seorang perajin colok gembrung di Dusun Pulo Maju, RT 02/04, Desa/Kecamatan Baregbeg, Ciamis. Ia sehari-hari berjualan colok gembrung di lorong kaki lima Blok A Pasar Manis, Ciamis.

Di Ciamis jika hendak membeli colok gembrung tidak terlalu sulit. Pedagang sayur keliling biasanya selalu menjajakan colok gembrung. Juga warungwarung kecil, warung nasi, penjual gorengan keliling hingga kantin sekolah, dan sebagainya. Jajanan pasar ini benarbenar merakyat di Ciamis. Harganya pun terjangkau sekitar Rp 5.000 per 10 tusuk. Menurut Teti, ia generasi keempat pembuat dan penjual colok gembrung ini. "Saya dulu suka diajak-ajak ibu saya jualan colok gembrung di pasar, ibu saya Mak Idah belajar dari bapaknya, Aki Suwita. Kakek saya belajar bikin colok gembrung dari orang tuanya."

Meskipun colok gembrung sudah lintas generasi, penampilan colok gembrung tidak berubah. Dari dulu sampai sekarang tidak mengalami perubahan, sajiannya ditusuk seperti sate dan bungkusnya tetap daun pisang. Sekarang yang berubah jenis bungkusnya. Biasanya memang pakai daun pisang. Tapi kini sudah mulai pakai kantong plastik, soalnya daun pisang sudah mulai sulit dan agak mahal.

\section{Opak Ketan}

Jenis makanan ini berasal dari bahan dasar beras ketan dan kelapa parut. Bumbu dan bahan yang digunakan adalah: garam, 
lumpang atau halu, daun pisang atau plastik, dan minyak goreng.

Cara pengolahannya: beras ketan yang telah ditanak ditumbuk, dicampur dengan kelapa parut dan garam. Setelah halus dicetak menjadi bulatan-bulatan kecil dengan menggunakan tangan yang dibungkus pelastik (semacam sarung tangan) kemudian diolesi dengan minyak kelapa. Adonan tadi digeleng-geleng atau diemple-emple hingga permukaannya menjadi rata dan tipis, besarnya tergantung selera. Kemudian dijemur sampai kering, baru kemudian digoreng atau dibakar di atas bara api.

\section{Saroja (Kembang Goyang)}

Jenis makanan ini terbuat dari bahan dasar tepung beras. Bumbu dan bahan atau alat yang digunakan adalah: gula putih, air, minyak goreg, cetakan, baskom, dan kuali. Cara pengolahan: tepung beras diseduh dengan air panas, kemudian diberi gula putih, untuk kue seroja manis, atau garam untuk kue seroja asin. Adonan dicetak dengan cara cetakan dicelupkan ke adonan tadi, kemudian digoreng.

\section{Ulen}

Makanan ini berasal dari bahan dasar beras ketan dan kelapa parut. Bumbu dan bahan yang digunakan:

- beras ketan $1 \mathrm{~kg}$,

- kelapa muda 1kepala, di parut,

- garam secukupnya,

- daun pisang atau plastik,

- minyak goring.

Cara pengolahan: beras ketan dicuci kemudian ditanak, setelah masak kemudian ditumbuk di dalam dulang dicampur dengan parutan kelapa dan sedikit garam, kemudian dieler yaitu digelarkan, diratakan permukaannya. Biasanya di atas daun pisang diolesi minyak goreng. Ketan kemudian dijemur supaya kering bagian luarnya, baru digoreng atau dibakar.

\section{Bugis Ketan}

Makanan ini berasal dari bahan dasar tepung beras ketan. Bumbu dan bahan yang digunakan:

- 250 gram tepung ketan,

- 50 gram tepung kanji,

- 1 sdt air kapur sirih,

- 75cc air daun suji dari 10 lembar daun suji dan 10 lembar daun pandan,

- 1/2 butir kelapa tidak terlalu tua, diparut,

- 250 gram gula merah diiris,

- 100 cc air,

- 1 sdt tepung beras,

- 1/4 sdt garam, daun pisang untuk membungkus.

Cara pengolahan: tepung beras ketan diseduh dengan air panas sampai adonan menjadi lembek. Untuk isinya, enten dibuat dari kelapa parut yang direbus dengan air gula merah, dibubuhi daun jeruk purut sebagai pewangi, lalu dibiarkan sampai mengering. Setelah itu adonan tepung dibentuk bulat-bulat, di dalamnya diisi dengan enten, kemudian dibungkus dengan daun pisang berbentuk persegi, agak menjorok di bagian tengah, dan dikukus sampai matang.

\section{Ranginang}

Makanan ini terbuat dari beras ketan. Bumbu yang digunakan: garam, terasi, penyedap rasa sesuai selera. Cara pengolahannya: beras ketan dicuci terlebih dahulu, kemudian ditanak, dicampur dan diaduk dengan terasi dan bumbu penyedap serta garam, sesuai selera. Setelah matang kemudian didinginkan sambil dicetak menjadi bulatan, lalu dijemur sampai kering, kemudian digoreng. 


\section{Kiripik Cau (Pisang)}

Makanan ini dibuat dari bahan dasar cau bagja, cau lampeneng, cau bawen, cau nangka, cau kapok. Bumbu dan bahan yang digunakan: air, gula putih atau gula merah, garam, minyak goreng. Alat yang digunakan adalah kuali dan baskom.

Cara pengolahan: pisang dikupas kulitnya kemudian diiris-iris ke arah memanjang atau melebar, untuk kiripik asin ditambah dengan garam secukupnya lalu diaduk sampai merata dan didiamkan sebentar supaya air garam meresap ke dalam irisan pisang, digoreng sampai matang. Untuk kiripik manis, setelah digoreng dimasukkan ke dalam gula merah atau putih yang telah dilumatkan, diadukaduk sampai gula mengering.

\section{Cimpring/Kicimpring}

Makanan ini berasal dari bahan dasar sampeu (singkong). Bumbu yang digunakan: garam, bawang daun, cengek atau cabe, ketumbar dan bumbu penyedap.

Cara pengolahan: singkong dikupas kulitnya kemudian dibersihkan dan diparut, setelah itu dicampurkan garam dan diberi irisan daun bawang secukupnya kemudian diaduk sampai merata. Adonan kemudian digelarkan sampai tipis dan dibentuk bulat lonjong. Diuap di atas tutup panci supaya agak lunak kemudian dijemur sampai kering lalu digoreng.

\section{Kiripik Sampeu (Singkong)}

Makanan ini terbuat dari bahan dasar singkong (sampeu). Bumbu dan bahan yang digunakan: air, garam minyak goreng. Alat yang dipakai adalah kuali, kukusan, nampan, dan tampah.

Cara pengolahan: sampeu (singkong) dikupas, dibersihkan, dikukus sampai matang. Setelah dingin kemudian diiris-iris tipis dan dijemur sampai kering. Kemudian digoreng sampai berwarna kekuning-kuningan dan ditaburi garam bubuk secukupnya.

\section{Sale Cau (Pisang)}

Bahan dasar yang digunakan adalah cau (pisang) siam dan cau (pisang) longgong yang sudah ladu (matang sekali), yang kulitnya sudah mulai terlihat agak membusuk.

Cara pengolahannya: cau (pisang) dikupas kulitnya, dialasi dengan sapu pare kemudian dijemur sampai kering.

\section{Nagasari}

Jenis makanan ini terbuat dari bahan dasar tepung beras, pisang raja, pisang nagka atau pisang ambon. Bumbu, bahan dan alat yang digunakan: santan kelapa, air, garam, daun pisang, alatnya kukusan.

Cara pengolahan: tepung beras diseduh dengan air santan hangat yang sudah dicampur dengan garam, diaduk sampai merata. Dibungkus persegi, di dalamnya diisi dengan potongan pisang, kemudian dikukus hingga matang.

\section{Sate Mang Etom}

Makanan ini terbuat dari bahan dasar daging ayam, daging domba dan daging sapi. Bumbu, bahan, alat yang digunakan: bawang merah, bawang putih, merica, garam, tempat pembakaran arang, arang, tusuk sate dan kipas.

Cara pengolahan: daging ayam, daging domba, daging sapi, dipotongpotong persegi kecil. Daging lalu dimasukkan ke dalam bumbu yang sebelumnya sudah ditumbuk supaya menyerap. Daging yang sudah dipotongpotong ditiir dengan tusuk sate yang terbuat dari bambu, kemudian dibakar di atas bara arang. 


\section{Kalua Jeruk}

Makanan ini terbuat dari bahan dasar kulit jeruk bali atau kulit jeruk jambang. Bumbu dan bahan yang digunakan adalah: air, kapur, gula pasir atau gula merah.

Cara pengolahannya: kulit jeruk dibuang bagian kulit yang hijau sampai terlihat putih, kemudian dipotong-potong, lalu dibersihkan dan direndam dengan air kapur. Kemudian jeruk digodog dengan air gula merah atau gula pasir sampai airnya mengering lalu dijemur.

\section{Kolontong}

Makanan kolontong dibuat dari bahan beras ketan dan kelapa. Bumbu dan alat yang digunakan: gula pasir, gula merah, garam, penyedap rasa, air, dan plastik.

Cara pengolahan: beras ditanak menjadi nasi, kemudian ditumbuk bersama-sama dengan kelapa yang sudah diparut, dicampur dengan gula merah. Setelah merata digelarkan sampai agak mengeras, lalu dipotong-potong dan dibakar di atas api. Gula pasir direbus, kemudian dimasukkan ketan yang sudah dibakar tadi ke dalam air gula lalu diadukaduk sampai mengering.

\section{Wajit Ketan}

Makanan ini terbuat dari bahan beras ketan. Bumbu dan bahan yang digunakan: kelapa parut, gula merah, gula pasir, vanili, kuali, kertas atau kararas (daun pisang yang sudah tua).

Cara pengolahan: beras ketan ditanak, setelah itu campurkan air gula, kelapa parut, dan vanili. Aduk hingga merata sampai adonan menjadi liat atau lengket. Kemudian didinginkan lalu dibungkus dengan kertas atau kararas yang sudah dipotong-potong.

\section{PENUTUP}

Makanan merupakan kebutuhan pokok hidup manusia, di samping sandang dan papan. Dalam makanan terpadu beberapa unsur yang dibutuhkan oleh yang memakannya. Secara sadar, orang yang memakan makanan biasanya lebih mengutamakan pada cita rasanya dibandingkan dengan manfaat makanan bagi kesehatan. Terlepas dari hal itu, keberadaan makanan tradisional suatu daerah dapat mengangkat citra positif daerah tersebut.

Setiap daerah memiliki makanan tradisional. Makanan tersebut ada yang asli daerah tersebut, ada juga yang mendapat pengaruh dari luar atau dibawa pendatang. Demikian pula makanan tradisional di Kabupaten Ciamis. Makanan asli yang menjadi ciri khas Ciamis dan telah ada sejak dahulu, relatif tidak terpengaruh oleh cita rasa makanan lain. Makanan asli Ciamis sendiri hanya sedikit mengalami perubahan, di antaranya pada cara pengolahan. Namun hal tersebut tidak sampai berpengaruh pada bentuk dan rasa makanannya.

Bahan makanan tradisional di Kabupaten Ciamis sangat terkait dengan kondisi geografis, terutama ketersediaan bahan baku makanan. Beras sebagai hasil pertanian sawah sangat banyak, mengingat Ciamis dikenal sebagai wilayah subur yang cocok untuk pertanian sawah. Keberadaan beras mendominasi kue-kue atau penganan yang dibuat. Beras ketan misalnya dapat dibuat kue secara langsung berupa beras atau terlebih dahulu diubah menjadi tepung. Beras ketan tersebut dicampur dengan bahan lain seperti gula merah, gula putih, serta diolah sedemikian rupa. Kebanyakan hasil dari olahan beras ketan tersebut berupa aneka macam makanan.

Aneka jenis buah pisang merupakan ciri khas Ciamis. Hampir di seluruh kawasan Ciamis, pohon pisang dan kelapa dapat tumbuh dengan subur. Tidak mengherankan penduduk atau petani yang 
memiliki pohon pisang dan kelapa dapat menjual pisang dan kelapa dalam jumlah banyak. Limpahan pisang ini banyak menghasilkan makanan dari pisang. Pembuatan kue dari pisang dilakukan dengan berbagai cara dan berbagai bahan campuran. Pengolahan kue dari pisang dilakukan dengan cara digoreng atau dikukus. Demikian pula bahan penyertanya, bisa berupa gula merah, gula putih, vanili, dan penyedap lainnya.

Buah kelapa pun merupakan hasil kebun yang sangat banyak. Hal ini dimanfaatkan pula sebagai bahan atau bumbu pada makanan atau penganan. Kelapa biasanya digunakan sebagai penyedap makanan atau penganan dengan cara diparut dan diperas untuk diambil santannya. Selain itu kelapa juga dapat dibuat menjadi minyak kelapa dan galendo. Promosi makanan dan penganan khas Ciamis biasanya dilakukan secara langsung melalui festival makanan atau dijual pada toko-toko. Dapat juga disisipkan berupa suguhan bagi pengunjung objek-objek wisata tertentu.

\section{DAFTAR SUMBER}

Adimihardja, Kusnaka. 2005.

Makanan dalam Khasanah Budaya: Relasi Kausal Antara Makanan dan Nilai Budaya Masyarakat Sunda di Jawa Barat.

Andayani, Ria. Dkk. 2005.

Ragam Makanan Tradisional Cirebo. Balai Kajian Sejarah dan Nilai Tradisional Bandung.

Andayani, Ria. Dkk. 2005.

Makanan Khas Ramadhan di Kabupaten Ciamis. Balai Kajian Sejarah dan Nilai Tardisional Bandung.

Rostyati, Ani. Dkk. 1995.

Sistem Ekonomi Pengrajian Rangginang di Kabupaten Bandung.
Balai Kajian Sejarah dan Nilai Tardisional Bandung.

Wawancara dengan Bapak Endut, pengrajin makanan Galendo tanggal 20 Juni 2011.

Wawancara dengan Ibu Ening Herminah, pengrajin makanan khas Ciamis tanggal 21Juni 2011. 